OPEN ACCESS

Edited by:

Simon Yona,

University College London,

United Kingdom

Reviewed by:

Ehud Zigmond,

Tel Aviv Sourasky Medical

Center, Israe

Prakash Ramachandran, University of Edinburgh, United Kingdom

*Correspondence: Marcus Altfeld

marcus.altfeld@/eibniz-hpi.de

tThese authors have contributed equally to this work

Specialty section:

This article was submitted to Antigen Presenting Cell Biology,

a section of the journal

Frontiers in Immunology

Received: 11 December 2018 Accepted: 16 May 2019

Published: 07 June 2019

Citation:

Martrus G, Goebels H, Langeneckert AE, Kah J, Flomm F Ziegler AE, Niehrs A, Löbl SM, Russu K, Hess LU, Salzberger W, Poch T, Nashan B, Schramm C, Oldhafer KJ, Dandri M, Koch M, Lunemann S and Altfeld M (2019) CD49a Expression Identifies a Subset of Intrahepatic Macrophages in Humans. Front. Immunol. 10:1247.

doi: 10.3389/fimmu.2019.01247

\section{CD49a Expression Identifies a Subset of Intrahepatic Macrophages in Humans}

\author{
Glòria Martrus ${ }^{1 \dagger}$, Hanna Goebels ${ }^{1 \dagger}$, Annika E. Langeneckert ${ }^{1}$, Janine Kah ${ }^{2,3}$, Felix Flomm ${ }^{1}$, \\ Annerose E. Ziegler ${ }^{1}$, Annika Niehrs ${ }^{1}$, Sebastian M. Löbl ${ }^{1}$, Kristina Russu ${ }^{1}$, \\ Leonard U. Hess ${ }^{1}$, Wilhelm Salzberger ${ }^{1}$, Tobias Poch ${ }^{2,4}$, Björn Nashan ${ }^{5,6}$, \\ Christoph Schramm ${ }^{2,4}$, Karl J. Oldhafer ${ }^{7}$, Maura Dandri ${ }^{2}$, Martina Koch ${ }^{5,8}$, \\ Sebastian Lunemann ${ }^{1+}$ and Marcus Altfeld ${ }^{1 * \dagger}$
}

\begin{abstract}
${ }^{1}$ Heinrich Pette Institute, Leibniz Institute for Experimental Virology, Hamburg, Germany, ${ }^{2}$ Internal Department of Medicine, University Medical Center Hamburg-Eppendorf, Hamburg, Germany, ${ }^{3}$ Center of Internal Medicine II, Brandenburg Medical School, University Hospital Brandenburg, Brandenburg, Germany, ${ }^{4}$ Martin Zeitz Center for Rare Diseases, University Medical Center Hamburg-Eppendorf, Hamburg, Germany, ${ }^{5}$ Department of Hepatobiliary and Transplant Surgery, University Medical Center Hamburg-Eppendorf, Hamburg, Germany, ${ }^{6}$ Clinic of Hepato-Pancreatico-Biliary Surgery and The Transplantation Center, First Affiliated Hospital, School of Life Sciences and Medical Center, University of Sciences \& Technology of China, Hefei, China, ${ }^{7}$ Department of General \& Abdominal Surgery, Asklepios Hospital Barmbek, Semmelweis University of Medicine, Hamburg, Germany, ${ }^{8}$ Department for General, Visceral and Transplant Surgery, University Hospital Mainz, Mainz, Germany
\end{abstract}

Macrophages play central roles in inflammatory reactions and initiation of immune responses during infections. More than $80 \%$ of total tissue macrophages are described to be located in the liver as liver-resident macrophages, also named Kupffer cells (KCs). While studies in mice have established a central role of liver-resident KCs in regulating liver inflammation, their phenotype and function are not well-characterized in humans. Comparing paired human liver and peripheral blood samples, we observed significant differences in the distribution of macrophage $(\mathrm{M} \varphi)$ subsets, with lower frequencies of $\mathrm{CD} 14^{\mathrm{hi}} \mathrm{CD} 16^{\mathrm{lo}}$ and higher frequencies of $\mathrm{CD} 14^{\text {int-hi }} \mathrm{CD} 16^{\text {int }} \mathrm{M} \varphi$ in human livers. Intrahepatic $\mathrm{M} \varphi$ consisted of diverse subsets with differential expression of CD49a, a liver-residency marker previously described for human and mice NK cells, and VSIG4 and/or MARCO, two recently described human tissue $M \varphi$ markers. Furthermore, intrahepatic $\mathrm{CD} 49 \mathrm{a}^{+} \mathrm{M} \varphi$ expressed significantly higher levels of maturation and activation markers, exhibited higher baseline levels of TNF- $\alpha, I L-12$, and IL-10 production, but responded less to additional in vitro TLR stimulation. In contrast, intrahepatic $\mathrm{CD}_{49 a^{-}} \mathrm{M} \varphi$ were highly responsive to stimulation with TLR ligands, similar to what was observed for CD49a- monocytes (MOs) in peripheral blood. Taken together, these studies identified populations of $\mathrm{CD}_{49 a^{+}}, \mathrm{VSIG} 4^{+}$, and/or MARCO${ }^{+} \mathrm{M} \varphi$ in human livers, and demonstrated that intrahepatic $\mathrm{CD} 49 \mathrm{a}^{+} \mathrm{M} \varphi$ differed in phenotype and function from intrahepatic $\mathrm{CD} 49 \mathrm{a}^{-} \mathrm{M} \varphi$ as well as from peripheral blood-derived monocytes.

\footnotetext{
Keywords: monocytes/macrophages, human liver, tissue residency, cell activation, CD49a
} 


\section{INTRODUCTION}

Under homeostatic conditions, the liver represents an immuneprivileged and tolerogenic organ, reflected by a general lack of immune responses induced by foreign antigens [with some exceptions, such as schistosomiasis (1)], and low rates of liver allotransplantation rejections $(2,3)$. The liver has however been suggested to play a central role in the regulation of host immune defenses $(4,5)$, as both gastrointestinal portal and systemic blood circulations reach the liver, exposing liverresident immune cells to antigens (6). Livers contain a large population of non-parenchymal immune cells, including hepatic stellate cells (HSC), dendritic cells (DCs), macrophages (M $\varphi$ ), Natural Killer (NK) cells and liver sinusoidal endothelial cells (LSEC) (7). M $\varphi$ and LSECs can absorb pathogens and molecules that entered the portal circulation after gastrointestinal translocation, as these cells are located within liver sinusoids, in close contact with the portal blood stream (8). Once peripheral blood monocytes migrate into tissues, they have been traditionally defined as $\mathrm{M} \varphi$, and serve as antigen presenting cells (APCs). In peripheral blood, MOs have been defined as $\mathrm{CD} 14^{\text {hi }} \mathrm{CD} 16^{\text {lo }}$ (classical), CD $14^{\text {int-hi }} \mathrm{CD} 16^{\text {int }}$ (intermediate), or $\mathrm{CD} 14^{\text {lo }} \mathrm{CD} 16^{\text {hi }}$ (non-classical) monocytes (9), with distinct functional capacities. In contrast, little is known about liverderived human $\mathrm{M} \varphi$, and the markers that characterize these cells. $\mathrm{M} \varphi$ in liver have been suggested to have dual origins, as they have the capacity to self-renew or to differentiate from recruited infiltrating peripheral blood monocytes (MOs) (10).

Liver-resident NK and T cells express CD49a, the alpha 1 subunit of $\alpha 1 \beta 1$ integrin, which retains cells in this organ by binding to two abundant molecules in the liver, collagen IV and laminin (11-15). Moreover, V-set and Ig domain-containing 4 (VSIG4), a molecule from the B7-related co-signaling family that binds to the complement component $3 \mathrm{~b}$ ( $\mathrm{C} 3 \mathrm{~b}$ and $\mathrm{iC} 3 \mathrm{~b}$ ), was identified as a cellular marker for liver-derived Kupffer cells (KC) in mice, and was also suggested to be a marker for human macrophages residing in peritoneum and livers (1622). Recently, an approach using RNA single cell sequencing of human liver tissues confirmed VSIG4 and identified the pattern recognition receptor (PRR) MARCO as specific markers of intrahepatic $\mathrm{M} \varphi(\mathrm{ihM} \varphi)$ (23). In mouse models, the presence of $\mathrm{VSIG}^{+}$KCs was critical in regulating responses of liverresident T- and NKT-cells (24), suggesting a role of this molecule in limiting inflammatory tissue damage. $\mathrm{MARCO}^{+}$cells were detected mainly in periportal areas of the liver and had lower responses to LPS/IFN- $\gamma$ stimulation (23). However, little is known about the expression of CD49a, VSIG4, and MARCO on human liver-derived $\mathrm{M} \varphi$, and the functionality of these cells.

In this study, matched peripheral blood MOs and intrahepatic $\mathrm{M} \varphi(\mathrm{ihM} \varphi)$ were phenotypically and functionally characterized to identify specific markers expressed by these different subpopulations. Our studies identified a population of $\mathrm{CD} 49 \mathrm{a}^{+}$, $\mathrm{VSIG}^{+}$, and/or $\mathrm{MARCO}^{+} \mathrm{ihM} \varphi$ in human livers. CD49a ${ }^{+}$ $\operatorname{ihM} \varphi$ exhibited cytokine responses at baseline and responded little to additional stimulation with TLR ligands. Altogether, our data suggest that CD49a serves as a marker to define intrahepatic
$\mathrm{M} \varphi$ and that $\mathrm{CD} 49 \mathrm{a}^{+} \mathrm{ihM} \varphi$ might play a role in regulating liver inflammation.

\section{MATERIALS AND METHODS}

\section{Study Cohort}

Matched peripheral blood and liver tissue samples were obtained from individuals undergoing liver transplant surgery (Department of Hepatobiliary and Transplant Surgery, University Medical Center Hamburg-Eppendorf) or surgical tumor-free liver tissue resection due to liver metastases (Department of General and Visceral Surgery at the Asklepios Clinic Hamburg-Barmbek). Demographics of individuals included in this study for each experiment set are shown in Supplementary Tables 1-4. Liver samples from a total of 33 individuals were used to generate the data in this study. Studies were approved by the Institutional Review Board of the medical faculty at the University of Hamburg (PV4898, PV4081, PV4780, and WF-021/11). All study subjects provided written informed consent.

\section{Cell Preparation}

Peripheral blood samples from each individual participating in this study were collected before or during surgery and processed within $2 \mathrm{~h}$. Peripheral blood mononuclear cells (PBMCs) samples were prepared using Ficoll-Hypaque centrifugation (Biocoll), as described previously $(25,26)$. Collected liver tissue was stored on ice for a maximum of $30 \mathrm{~min}$ before processing and mechanically sliced into pieces of $0.5-1 \mathrm{~cm}^{3}$ under BSL3 ${ }^{* *}$ laboratory conditions (Biosafety Level $3^{* *}$ ), as described (14, 27). If the amount of isolated liver cells obtained was higher than $1 \times 10^{9}$ total cells, an additional purification step was performed. In brief, cells were diluted with PBS, centrifuged twice at $40 \mathrm{xg}$ for $4 \mathrm{~min}$ at room temperature (RT) and supernatant containing intrahepatic leukocytes (IHLs) was recovered and transferred to a new tube. PBS was added to obtain a final volume in the tube of $50 \mathrm{~mL}$, cells were centrifuged at $400 \mathrm{xg}$ for $7 \mathrm{~min}$ and supernatant was discarded. This washing step was repeated twice. Cell pellets were resuspended in $4.5 \mathrm{~mL}$ PBS (final volume) and mixed with OptiPrep solution (SigmaAldrich) in a $15 \mathrm{~mL}$ falcon tube. $1 \mathrm{~mL}$ of PBS was carefully layered on top of the cell/Optiprep suspension and tubes were centrifuged for $20 \mathrm{~min}$ at $400 \mathrm{xg}$ without breaks. The interphase containing the erythrocyte/leukocyte populations was collected and cells were washed once with PBS. The cell pellet containing intrahepatic leukocytes (IHLs) was treated with ACK Lysis buffer (Sarsted AG\&Co) following manufacturer's instructions and finally resuspended in RPMI $+10 \%$ FBS for subsequent experiments. Enzymatic treatment was not used to avoid cleavage and degradation of cell surface receptors [data not shown and (28)].

\section{Phenotyping of Monocytes/ $\mathrm{M} \varphi$ Populations Using Flow Cytometry}

Freshly isolated IHLs and PBMCs $\left(2 \times 10^{6}\right.$ cells $)$ were used for flow cytometry phenotyping and the same voltages and settings were applied on paired samples. For the surface staining we 
used the antibodies summarized in Supplementary Table 5. Zombie aqua (Biolegend) was used to discriminate dead cells. Cells were analyzed using a BD LSR Fortessa and further analyses were performed with FlowJov10 software. The same gating strategy was applied for PBMCs and IHLs from the same donor in the analysis of monocytes $/ \mathrm{M} \varphi$ populations (Supplementary Figures 1A,B). t-SNE analyses were performed using the Cytobank (USA) platform. The corresponding isotype controls for VSIG4, CD49a and MARCO staining are shown in Supplementary Figure 2A and Supplementary Table 5. MARCO was not well-detectable in unstimulated freshly isolated samples using flow cytometry. To test for antibody specificity, freshly isolated PBMCs were polarized with recombinant human M-CSF (Peprotech) at $40 \mathrm{ng} / \mathrm{mL}$ for 5 days, followed by IL-10 stimulation (Peprotech) at $10 \mathrm{ng} / \mathrm{mL}$ for $48 \mathrm{~h}$, as recommended by the vendor (Thermofisher). Cells were stained to define monocytes/macrophages and MARCO (Supplementary Figure 2B).

\section{Immunofluorescence}

To visualize the expression of surface markers CD49a CD68, MARCO, and VSIG4 on $\mathrm{M} \varphi$, frozen human liver biopsies were cut in $5 \mu \mathrm{m}$ sections. To control for tissue and cellular morphology, $12 \mu \mathrm{m}$ slides were also prepared and stained with Hoechst, as described below. Tissue slides were fixed and permeabilized in acetone for $10 \mathrm{~min}$ at RT, washed three times with $1 \times$ PBS, blocked for 30 min with $10 \%$ BSA in PBS and subsequently incubated overnight at $4{ }^{\circ} \mathrm{C}$ with the following antibodies: CD49a (FITC; TS217; Biolegend, dilution 1:100), CD68 (AF 405 or PE; JO217; Santa Cruz; dilution 1:100), MARCO (unlabeled; polyclonal; Invitrogen; 1:100) and VSIG4 (APC or PE-Cy7; JAV4; eBioscience; dilution 1:100). When MARCO staining was performed, slides were washed three times with $0.1 \% \mathrm{BSA} / 1 \times \mathrm{PBS}$ for $5 \mathrm{~min}$ each and a secondary goat anti-rabbit antibody was used (AF633; Invitrogen; 1:400). Tissue sections that were not stained with CD68-AF405 antibody were stained with Hoechst for $2 \mathrm{~min}$. Tissue slides were mounted with fluorescein mounting media (Dako, Glostrup, Denmark) and visualized by confocal laser scanning microscopy (Microscope Biorevo BZ-9000, Keyence, Japan) using the same settings for all recorded areas. Unstained samples were used to assess the autofluorescence background of tissue samples and used to set the sensitivity of detectors (Supplementary Figure 3A). Fiji (ImageJ) was used to analyze all data, using a macro (Fiji measurement analyzer) (Supplementary Code 1), aiming at first applying a positive mask on $\mathrm{CD}^{+} 8^{+}$signal $(n=561)$ and then calculating the signal presence and intensity on $\mathrm{CD}^{+} 8^{+}$signal for VSIG4, MARCO and CD49a. The specificity of the binary definition of signals and their intensities defined by the macro on Fiji showed a reliable gating strategy (Supplementary Figure 4).

\section{Intracellular Cytokine Staining}

Functional responses of monocytes and macrophages to TLR4 or TLR7/8 ligands were assessed in cell cultures of PBMCs or OptiPrep-isolated IHLs stimulated with either LPS $(100 \mathrm{ng} / \mathrm{mL}$, Invivogen) or CL097 ( $1 \mu \mathrm{g} / \mathrm{mL}$, Invivogen $)$ in a medium containing BFA $(5 \mu \mathrm{g} / \mathrm{mL}$, Sigma Aldrich), as previously described (29). Unstimulated cells were used as baseline control. At $16 \mathrm{~h}$ post-stimulation, cells were prepared for intracellular cytokine staining following the manufacturer's instructions (FIX \& PERM ${ }^{\circledR}$ Cell Fixation \& Cell Permeabilization Kit, Thermo Fisher Scientific) and antibodies from Supplementary Table 5. Cells were washed and measured using a BD LSR Fortessa. Further analyses and gating strategies were performed with FlowJo v10 software.

\section{Statistical Analysis}

Statistical analyses were performed using Prism v7.03 (GraphPad Software Inc.). Since the sample size for the individual comparisons was under $n=30$, data was analyzed as nonnormally distributed (non-parametric). Matched analyses were performed using Wilcoxon matched pair signed rank test for comparisons and adjusted for multiple comparisons (FDR) using the original FDR method of Benjamini and Hochberg $(\mathrm{Q}=$ $1 \%)$. When samples were not paired, Mann-Whitney tests were applied. When not otherwise stated, $p$ values $<0.05$ were considered as statistically significant and were depicted in the corresponding figures.

\section{RESULTS}

\section{CD49a Is Expressed by Intrahepatic M $\varphi$}

Monocytes and $\mathrm{M} \varphi$ play a pivotal role in liver homeostasis and initiation of immune responses. We analyzed and compared the phenotypical profile of human peripheral blood monocytes (pbMOs) and intrahepatic $\mathrm{M} \varphi(\mathrm{ihM} \varphi)$ using flow cytometry. While no differences were observed in the $\mathrm{CD} 14^{\mathrm{lo}} \mathrm{CD} 16^{\mathrm{hi}}$ subset between liver and peripheral blood (Figure 1A), the proportion of $\mathrm{CD} 14^{\text {int-hi }} \mathrm{CD} 16^{\text {int }}$ cells was significantly upregulated and the proportion of $\mathrm{CD} 14^{\text {hi }} \mathrm{CD} 16^{\text {lo }}$ cells downregulated in liverderived cells compared to peripheral blood (Figure 1A). In a representative t-SNE plot, monocytes and $\mathrm{M} \varphi$ from PBMCs and liver diverged substantially, specially due to the differential expression of CD49a, CD80, CD83, CD69, and CD86 (Figure 1B, Supplementary Figures 1C,D).

The activation status of monocytes/ $\mathrm{M} \varphi$ was analyzed using CD69 (30), CD83 (31), CD80 (B7.1), and CD86 (B7.2) (32). Compared to pbMOs, ihM $\varphi$ contained a lower proportion of cells expressing activation markers such as CD69, CD80, and CD86 (Figure 1C). IhM $\varphi$ however contained almost exclusively a population of $\mathrm{CD}_{4} \mathrm{a}^{+}$cells, which was very rare in pbMOs (Figure 1C), similarly to what has been described for intrahepatic NK cells $(11,14)$. No differences in the expression of the studied markers were observed between $\mathrm{CD} 14^{\mathrm{lo}} \mathrm{CD} 16^{\mathrm{hi}}$, $\mathrm{CD} 14^{\text {int-hi }}{ }^{\mathrm{CD}} 16^{\mathrm{int}}$, and $\mathrm{CD} 14^{\mathrm{hi}} \mathrm{CD} 16^{\mathrm{lo}}$ monocytes/M $\varphi$ (data not shown). We subsequently gated on $\mathrm{CD} 49 \mathrm{a}^{+}$and $\mathrm{CD} 49 \mathrm{a}^{-}$ $\mathrm{ihM} \varphi$ and compared the proportion of cells expressing activation markers. Compared to $\mathrm{CD} 49 \mathrm{a}^{-} \mathrm{ihM} \varphi, \mathrm{CD} 49 \mathrm{a}^{+}$ihM $\varphi$ contained higher proportion of cells expressing CD69, CD80, CD83, and CD86 (Figure 1D). Taken together, the data demonstrate that $\mathrm{CD} 49 \mathrm{a}$, but not $\mathrm{CD} 69$, can serve as a marker to identify intrahepatic $\mathrm{M} \varphi$, and that $\mathrm{CD} 49 \mathrm{a}^{+} \mathrm{ihM} \varphi$ represent the main $\mathrm{M} \varphi$ population in livers expressing molecules of cellular activation. 


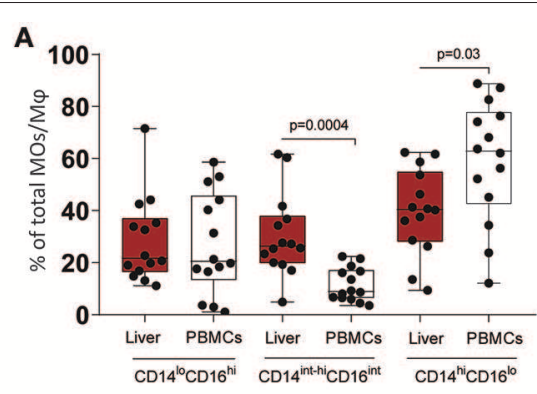

$\mathbf{B}$
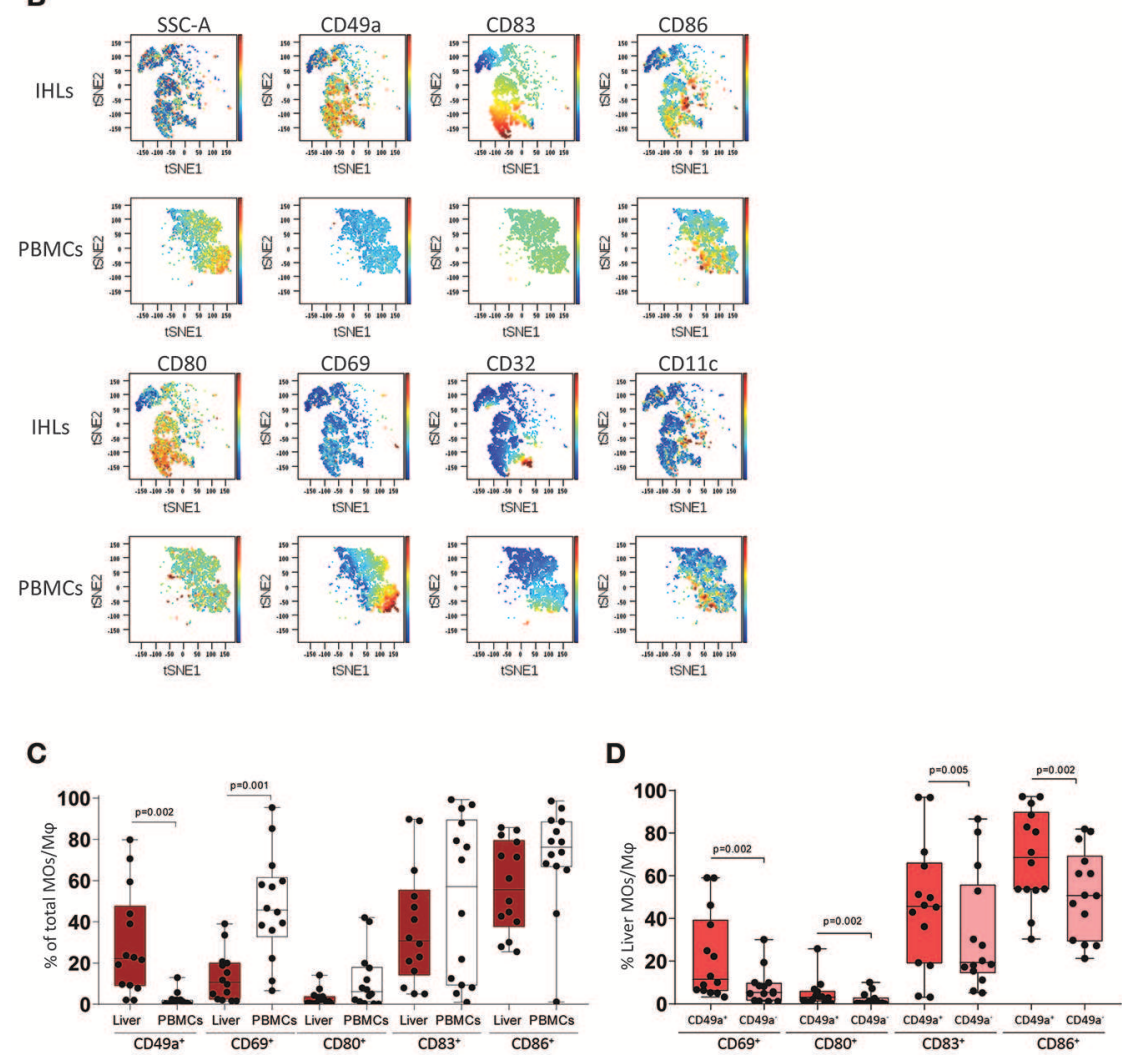

FIGURE 1 | Immunophenotyping of macrophages (M $\varphi$ ) and monocytes (MOs) in leukocytes from liver (IHLs) and blood (PBMCs). (A) Comparison of cell subset distribution between intrahepatic leukocytes (IHLs) (dark red) and matched peripheral blood mononuclear cells (PBMCs) (white) ( $n=14)$. (B) t-SNE analysis of one representative sample showing the expression of CD49a, CD83, CD86, CD32, CD80, CD11c, and CD69 in both PBMCs and IHLs. (C) Scatter plots showing the

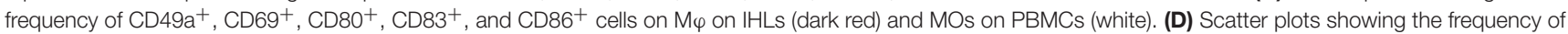
$\mathrm{CD}^{+}{ }^{+}, \mathrm{CD}^{+}{ }^{+}, \mathrm{CD}^{+} 3^{+}$, and $\mathrm{CD} 86^{+}$cells on $\mathrm{CD} 49 \mathrm{a}^{+} \mathrm{ihM} \varphi$ (red) and $\mathrm{CD} 49 \mathrm{a}^{-}$ihM $\varphi$ (salmon). Median with min-max range is shown ( $n=14$ ). All samples were analyzed using Mann-Whitney test and were additionally corrected for test-multiplicity using the original FDR method of Benjamini and Hochberg. Only statistically significant $p$-values are shown.

\section{CD49a, VSIG4, and MARCO Serve as Markers for Intrahepatic $M \varphi$}

To further characterize $\mathrm{CD} 49 \mathrm{a}^{+} \mathrm{ihM} \varphi$ in livers, CD68, VSIG4, and MARCO, three markers recently described to help define monocyte and macrophages in tissues $(18,23,33)$, were used to stain $\mathrm{CD} 49^{+} \mathrm{ihM} \varphi$ by immunofluorescence of frozen acetonefixed liver tissue slides. The staining confirmed that CD49a, MARCO and VSIG4 were expressed in liver tissues, as previously described in mice or humans $(11,14,20,23,27)$, including on hepatocytes (Figure 2A, Supplementary Figures 3A,B). Liver tissues furthermore contained a high number of $\mathrm{CD}^{+} 8^{+}$ cells, indicating high numbers of monocytes $\mathrm{M} \varphi$ (Figure 2A, Supplementary Figure 3). Specifically, our results showed that $\mathrm{VSIG}^{+} \mathrm{M} \varphi$ in liver tissues, defined as positive for CD68, can also co-express CD49a and MARCO (Figures 2A,B). Boolean gating on the measured CD49a, VSIG4, and MARCO on $\mathrm{CD}^{+} 8^{+}$signals showed distinct populations of intrahepatic macrophages expressing different combinations of the three markers (Figure 2B). The three most prominent populations were either co-expressing all three markers, co-expressing VSIG4 
and MARCO or none of the markers (Figure 2B). The presence of $\mathrm{CD}^{+} 8^{+}$signals only co-expressing MARCO and CD49a was scarce. Signal intensities of CD49a and VSIG4, as well as VSIG4 and MARCO, significantly correlated, indicating a strong co-expression pattern, while signal intensities of CD49a and MARCO did not correlate (Figure 2C). Furthermore, a binary analysis assessing the signal intensity of the three investigated markers (CD49a, MARCO and VSIG4) on populations either positive or negative for one of the other markers showed higher intensity for the respective markers on positive cells, with for example significantly higher CD49a intensity on $\mathrm{VSIG}^{+}$signals compared to VSIG4 ${ }^{-}$signals (Figure 2D). The only exception was CD49a intensity on MARCO $^{+/-}$signals (Figure 2D). Taken together, these data show the expression of CD49a, MARCO and VSIG4 on liver-derived $\mathrm{M} \varphi$ populations, and identified $\mathrm{M} \varphi$ populations expressing different combination of these markers.

To confirm the immunofluorescence results, we subsequently stained matched unstimulated freshly-derived liver and PBMCs samples directly ex vivo for VSIG4, CD49a, and MARCO, and quantified marker expression using flow cytometry. $\mathrm{CD} 49 \mathrm{a}^{+} \mathrm{ihM} \varphi$ showed significantly higher median fluorescence intensities (MdFIs) of VSIG4- and also MARCO-expression compared to $\mathrm{CD}_{49} \mathrm{a}^{-}$ihM $\varphi$ or PBMCs (Figures 3A,B). CD49a and MARCO MdFIs were furthermore significantly higher on $\mathrm{VSIG}^{+}{ }^{+} \mathrm{ihM} \varphi$ compared to VSIG4 ${ }^{-}$ihM $\varphi$ (Figures 3C,D), and VSIG4 and CD49a MdFIs were higher on MARCO ${ }^{+}$cells compared to $\mathrm{MARCO}^{-}$cells (Figures 3E,F). These data acquired using multiparameter flow cytometry therefore largely mirrored data acquired by immunofluorescence analysis of liver samples. Overall, the data obtained with the two different techniques showed that CD49a, MARCO, and/or VSIG4 can be used as markers to identify intrahepatic $\mathrm{M} \varphi$.

\section{ihM $\varphi$ Have a Higher Baseline Activation Status Compared to pbMOs}

To study the functional activity of $\operatorname{ihM} \varphi$, we subsequently stimulated isolated IHLs and PBMCs with LPS (TLR4 stimulation) or CL097 (TLR7/8 stimulation), and used unstimulated cells to control for baseline activation. The proportion of cells expressing TNF- $\alpha$ and IL-12, proinflammatory cytokines secreted by $\mathrm{MOs}$ and $\mathrm{M} \varphi$, as well as IL-10, an anti-inflammatory cytokine, were quantified using flow cytometry. Compared to unstimulated cells, LPS- and CL097-stimulations significantly increased the proportion of TNF- $\alpha^{+}, \mathrm{IL}-12^{+}$, and IL- $10^{+}$cells (Figure 4A, left panels). $\operatorname{IhM} \varphi$ responded to LPS and CL097 stimulation by increasing the proportion of TNF- $\alpha^{+}$and $\mathrm{IL}-12^{+}$cells when compared to unstimulated cells (Figure 4A, left panel). No or little increase in $\mathrm{IL}-10^{+} \mathrm{ihM} \varphi$ was observed after stimulation with LPS compared to baseline levels (Figure 4A, lower left panel). When comparing pbMOs and $\operatorname{ihM} \varphi, \operatorname{ihM} \varphi$ included a significantly higher proportion of TNF- $\alpha^{+}, \mathrm{IL}-12^{+}$and IL- $10^{+}$cells already at baseline, prior to stimulation (Figure 4A, right panel). CL097and LPS-stimulations increased the proportion of TNF- $\alpha^{+}$ cells similarly in pbMOs and $\mathrm{ihM} \varphi$ (Figure 4A, right panel), and LPS-stimulation also increased the proportion of IL-12 ${ }^{+}$ and $\mathrm{IL}-10^{+} \mathrm{ihM} \varphi$ when compared to pbMOs (Figure 4A, right panel). Altogether, our data showed that $\operatorname{ihM} \varphi$ have a higher baseline production of cytokines, but are less reactive to further stimulation compared to pbMOs.

We subsequently compared cytokine production between $\mathrm{CD}_{49} \mathrm{a}^{+}$and $\mathrm{CD} 49 \mathrm{a}^{-} \mathrm{ihM} \varphi$. Upon stimulation, CD49a ${ }^{-} \mathrm{ihM} \varphi$ significantly increased the proportion of TNF- $\alpha^{+}, \mathrm{IL}-12^{+}$, and IL- $10^{+}$cells (the latter only with LPS stimulation) while the proportion of cytokine-positive cells was maintained at high levels within the $\mathrm{CD} 49 \mathrm{a}^{+} \mathrm{ihM} \varphi$ population (Figure $4 \mathrm{~B}$, left panel). $\mathrm{CD} 49 \mathrm{a}^{+} \mathrm{ihM} \varphi$ represented the main $\mathrm{M} \varphi$ population in livers already producing TNF- $\alpha$, IL-12, and IL-10 at baseline without TLR-stimulation, and levels of cytokine production upon stimulation with LPS and CL097 were generally higher in $\mathrm{CD}_{49} \mathrm{a}^{+} \mathrm{ihM} \varphi$ compared to $\mathrm{CD} 49 \mathrm{a}^{-} \mathrm{ihM} \varphi$ (Figure 4B, right panels). Finally, we assessed the polyfunctionality of all analyzed cell subsets based on IL-10, IL-12, and TNF- $\alpha$ production, including pbMOs, ihM $\varphi$ and $\mathrm{CD} 49 \mathrm{a}^{+/-} \mathrm{ihM} \varphi$ using Boolean gating. Cells were stratified into 4 subsets depending on the number of cytokines produced (0-3). The number of cells producing one or more cytokines increased for all populations following stimulation with TLR ligands (Figure 5A). Following stimulation with LPS, ihM $\varphi$ and in particular $\mathrm{CD} 49 \mathrm{a}^{+} \mathrm{ihM} \varphi$ included polyfunctional cells that produced 2 or more cytokines, while similar fractions of 2 or more cytokine-producing cells were observed across all cell subsets following CL097-stimulation (Figure 5A). A detailed analysis revealed that TNF- $\alpha$ was the main cytokine produced by unstimulated $\operatorname{CD} 49 \mathrm{a}^{+} \mathrm{ihM} \varphi$, alone or in combination with IL-10 (Figure 5B). Upon LPSstimulation, pbMOs and $\mathrm{CD} 49 \mathrm{a}^{-} \mathrm{ihM} \varphi$ had a similar cytokine pattern, while $\mathrm{CD} 49 \mathrm{a}^{+} \mathrm{ihM} \varphi$ contained higher proportion of TNF- $\alpha^{+}$IL-12 ${ }^{+}$cells (Figure 5B). In summary, CD49 ${ }^{+} \mathrm{ihM} \varphi$ exhibited higher baseline cytokine production compared to $\mathrm{CD}_{49} \mathrm{a}^{-} \mathrm{ihM} \varphi$ cells, resulting in relatively smaller increases in cytokine production in response to further in vitro LPS or CL097 stimulations than observed for $\mathrm{CD} 49 \mathrm{a}^{-} \mathrm{ihM} \varphi$ or pbMOs.

\section{DISCUSSION}

The liver plays a central role in regulating immune responses and inflammation. Antigen-presenting cells in the liver, such as intrahepatic $M \varphi$, sense and recognize pathogenassociated and danger-associated molecular patterns through pattern recognition receptors (PRRs) (34). The localization of intrahepatic $\mathrm{M} \varphi$ within the liver sinusoids in close proximity to LSECs has been suggested to be essential for the functionality of intrahepatic $\mathrm{M} \varphi$. During acute or chronic liver diseases, intrahepatic $\mathrm{M} \varphi$ have been described to control liver injury by shaping an anti-inflammatory liver immune response (35). However, due to limited availability of human liver samples, very little is known about the phenotype and function of human liver $\mathrm{M} \varphi$. Here we show that intrahepatic $\mathrm{M} \varphi$ can be identified based on the expression of the integrin $\alpha 1$ receptor CD49a, similar to intrahepatic NK cells $(11,14)$, the complement component 3 receptor VSIG4 and MARCO. Our results furthermore demonstrate that liver-derived $\mathrm{CD}_{49} \mathrm{a}^{+} \mathrm{ihM} \varphi$ cells exhibit 


\section{A}

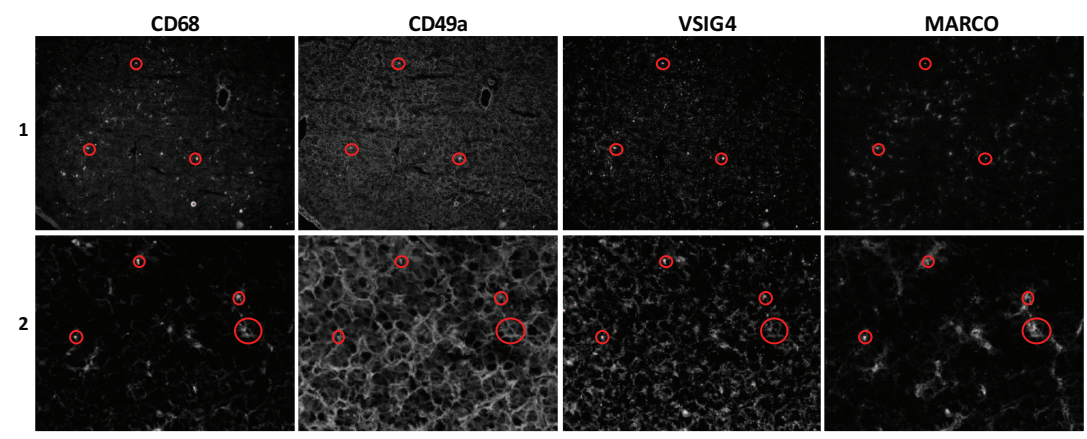

B
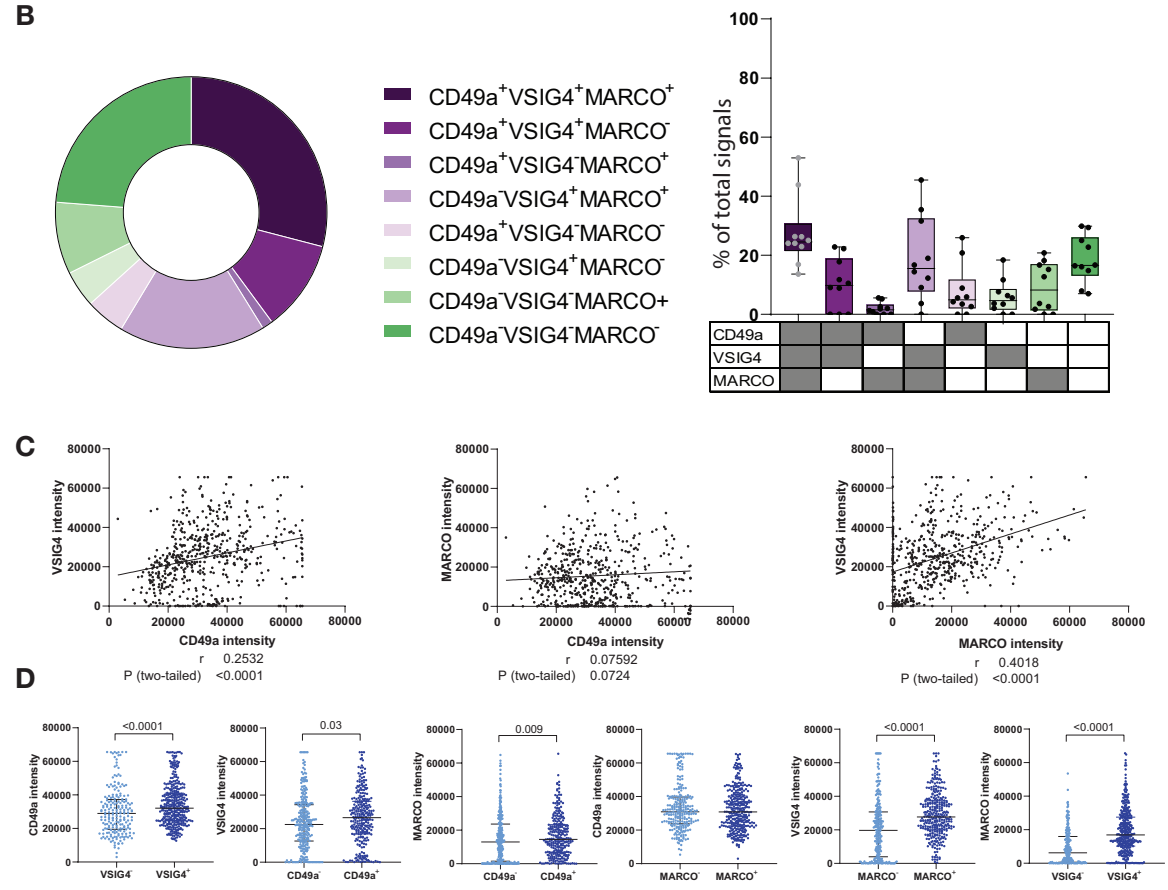

FIGURE 2 | Immunofluorescence data showing CD49a, VSIG4 and MARCO expression in human intrahepatic macrophages. (A) Representative immunofluorescence staining of CD68, CD49a, VSIG4, and MARCO in frozen and acetone-fixed liver tissue sections in two liver samples. The red circles depict examples of co-expression of the four markers. (B) Boolean gating on masked CD68 ${ }^{+}$signals defining CD49a, VSIG4 and MARCO signal combinations ( $n=561$ signals from 10 tissue slides). (C) Correlation plots between CD49a and VSIG4 signal intensity (left), CD49a and MARCO (middle) and MARCO and VSIG4 (right) in cells defined as CD68 ${ }^{+}(n=561$ pairs). (D) Scatter plots showing signal intensities of CD49a, MARCO and VSIG4 on CD68 ${ }^{+}$cells, categorized by VSIG4 ${ }^{+/-}\left(n=209\right.$ for VSIG4 ${ }^{-}$and $n=352$ for

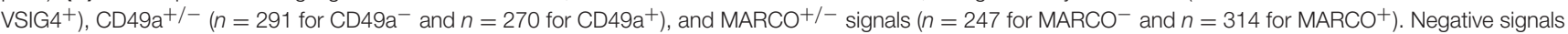
for each marker are represented in light blue and positive signals in dark blue. Median is depicted and error bars indicate the interquartile range, $p$-value determined by Mann-Whitney test.

an increased baseline production of cytokines and higher expression of maturation and activation markers compared to $\mathrm{CD} 49 \mathrm{a}^{-} \mathrm{ihM} \varphi$.

Monocytes and $\mathrm{M} \varphi$ can be sub-classified depending on the expression of cell surface markers into classical $\mathrm{CD} 14^{\text {hi }} \mathrm{CD} 16^{\text {lo }}$, intermediate $\mathrm{CD} 14^{\text {int-hi }} \mathrm{CD} 16^{\text {int }}$ and nonclassical $\mathrm{CD} 14^{\mathrm{lo}} \mathrm{CD} 16^{\mathrm{hi}}$ cells, each exhibiting different functions (9). The $\mathrm{CD} 14^{\text {lo }} \mathrm{CD} 16^{\text {hi }}$ monocytes and $\mathrm{M} \varphi$ subset has been associated with inflammatory responses including immune activation and antigen presentation, while $\mathrm{CD} 14^{\text {hi }} \mathrm{CD} 16^{\text {lo }}$ and
$\mathrm{CD} 14^{\text {int-hi }}{ }^{\mathrm{CD}} 16^{\text {int }}$ monocytes and $\mathrm{M} \varphi$ subsets preferentially exert phagocytic functions (36). Comparing peripheral bloodand liver-derived $\mathrm{M} \varphi$ from the same study subjects, we observed that the proportion of $\mathrm{CD} 14^{\text {int-hi }} \mathrm{CD} 16^{\text {int }}$ cells in $\operatorname{ihM} \varphi$ was higher than in matched pbMOs. In contrast, $\mathrm{CD} 14^{\text {hi }} \mathrm{CD} 16^{\text {lo }}$ monocytes and $\mathrm{M} \varphi$ subsets were present in a lower proportion within $\operatorname{ihM} \varphi$ when compared to pbMOs, confirming previous studies (10). CD $14^{\text {int-hi }}$ CD $16^{\text {int }}$ monocytes have been suggested to possess inflammatory functions, as they are often expanded in inflammatory disorders (37). Expansion 
A

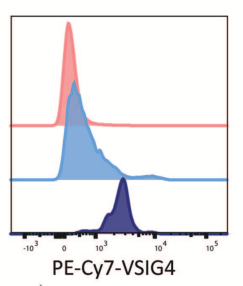

C

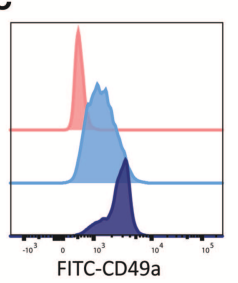

E

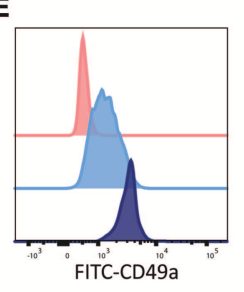

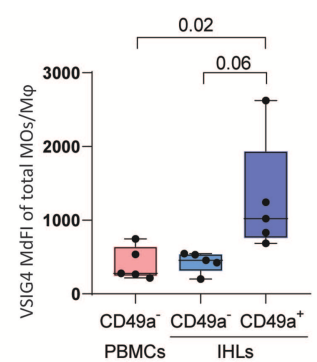

B
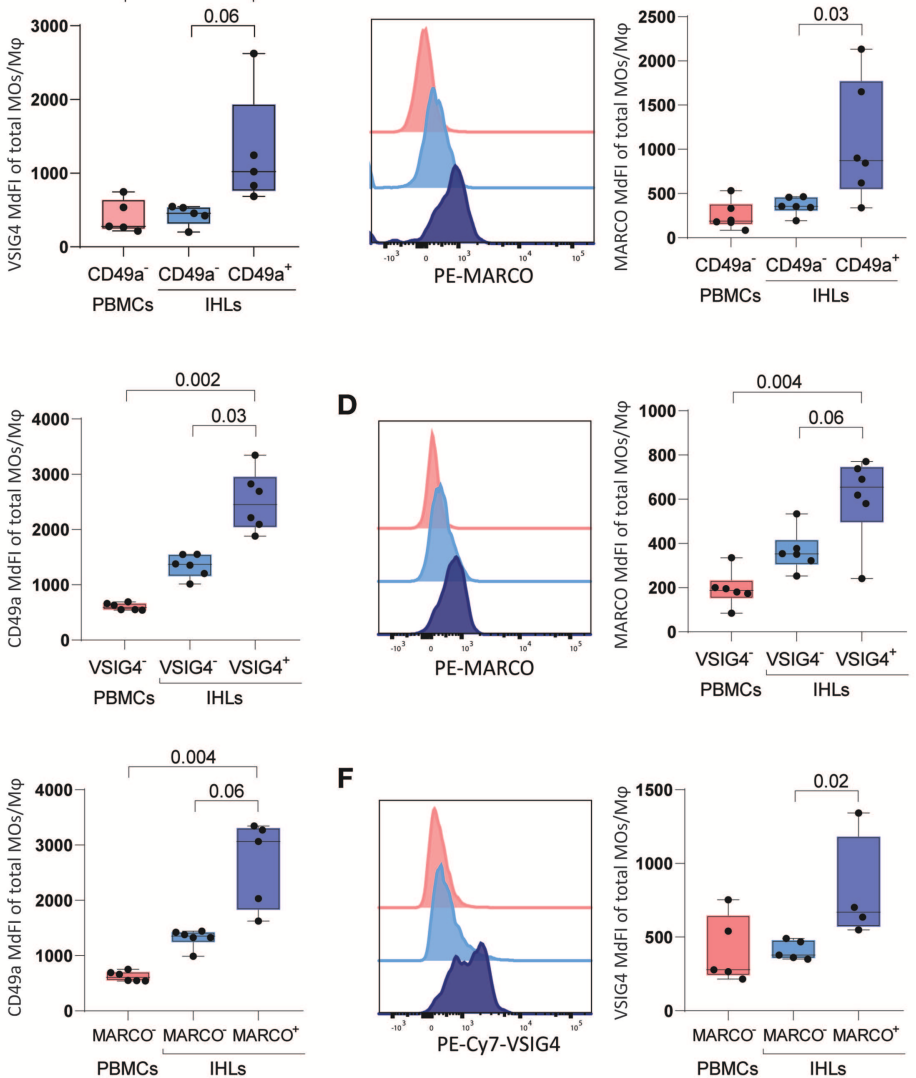

D

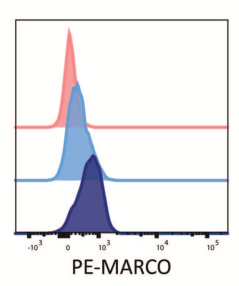

F
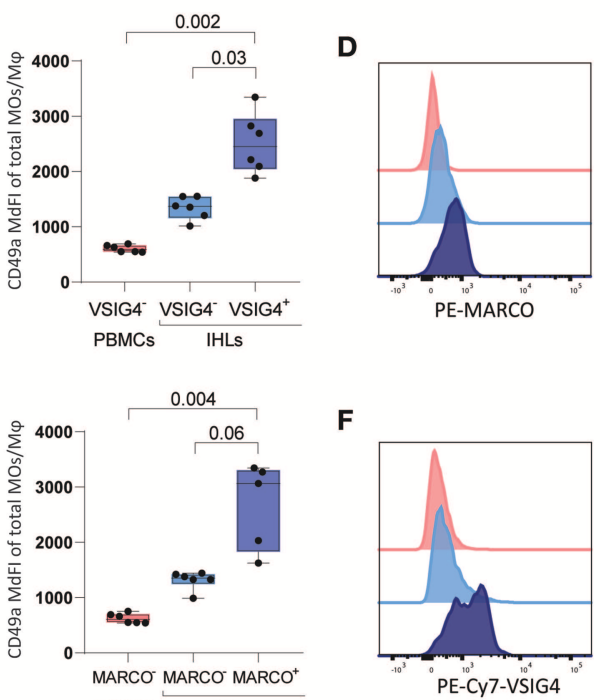
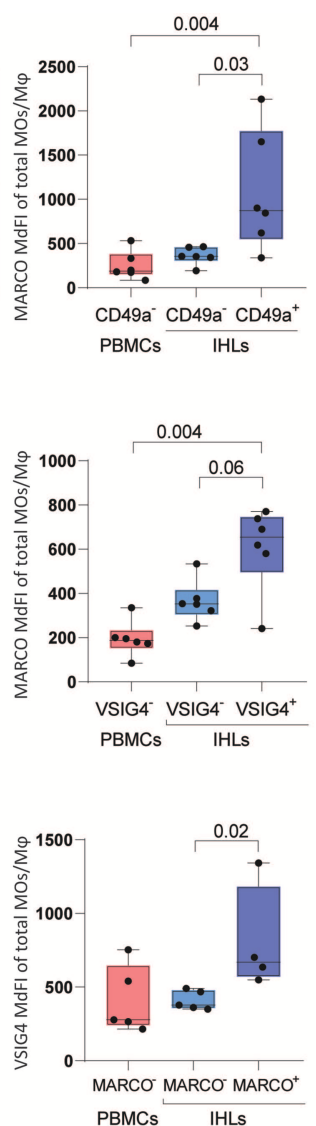

FIGURE 3 | Expression of VSIG4, MARCO and CD49a on freshly isolated PBMCs and IHLs (A) (left) Representative histogram of VSIG4 expression on gated CD49aPBMCs (red), CD49a- ihM $\varphi$ (light blue), and CD49a+ ihM $\varphi$ (dark blue). (right) Scatter plot summarizing VSIG4 MdFI on CD49a- PBMCs (red), CD49a- ihM $\varphi$ (light

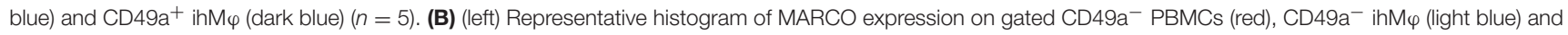
$\mathrm{CD}_{9} \mathrm{a}^{+}$ihM $\varphi$ (dark blue). (right) Scatter plot summarizing MARCO MdFI on CD49a ${ }^{-}$PBMCs (red), CD49a ${ }^{-}$ihM $\varphi$ (light blue) and CD49a ${ }^{+}$ihM $\varphi$ (dark blue) $(n=6)$. (C) (left) Representative histogram of CD49a expression on gated VSIG4- PBMCs (red), VSIG4- ihM $\varphi$ (light blue) and VSIG4 ${ }^{+}$inM $\varphi$ (dark blue). (right) Scatter plot summarizing CD49a MdFI on VSIG4- PBMCs (red), VSIG4- ihM $\varphi$ (light blue) and VSIG4+ ihM $\varphi$ (dark blue) $(n=6)$. (D) (left) Representative histogram of MARCO expression on gated VSIG4 ${ }^{-}$PBMCs (red), VSIG4 ${ }^{-}$ihM $\varphi$ (light blue) and VSIG4+ ihM $\varphi$ (dark blue). (right) Scatter plot summarizing MARCO MdFI on VSIG4- PBMCs (red), VSIG4- ihM $\varphi$ (light blue) and VSIG4+ ihM $\varphi$ (dark blue) $(n=6)$. (E) (left) Representative histogram of CD49a expression on gated MARCO- PBMCs (red), $\mathrm{MARCO}^{-}$ihM $\varphi$ (light blue) and $\mathrm{MARCO}^{+}$ihM $\varphi$ (dark blue). (right) Scatter plot summarizing CD49a MdFI on MARCO- PBMCs (red), MARCO- inM $\varphi$ (light blue) and $\mathrm{MARCO}^{+} \mathrm{ihM}_{\varphi}$ (dark blue) ( $n=6$ for PBMCs and MARCO- $\mathrm{HLS}^{-} n=5$ for MARCO $\left.{ }^{+} \| \mathrm{HLs}\right)$. (F) (left) Representative histogram of VSIG4 expression on gated $\mathrm{MARCO}^{-} \mathrm{PBMCs}^{\mathrm{red}}$ ), MARCO${ }^{-}$ihM $\varphi$ (light blue) and $\mathrm{MARCO}^{+}$ihM $\varphi$ (dark blue). (right) Scatter plot summarizing VSIG4 MdFI on MARCO- PBMCs (red),

$\mathrm{MARCO}^{-}$ihM $\varphi$ (light blue) and $\mathrm{MARCO}^{+} \operatorname{ihM} \varphi$ (dark blue) ( $n=5$ for PBMCs and MARCO- $\mathrm{HLS}, n=4$ for MARCO ${ }^{+} \|_{\mathrm{HLs}}$ ). One sample was excluded due to the low proportion of $\mathrm{MARCO}^{+}$cells. Median is depicted and error bars indicate the min-max range, $p$-value determined by Mann-Whitney test (PBMCs vs. IHLs) and Wilcoxon matched-pairs signed rank test when comparing $I H L$ populations.

of $\mathrm{CD} 14^{\text {int-hi }} \mathrm{CD} 16^{\text {int }}$ ihM $\varphi$ during fibrosis/cirrhosis has been demonstrated, indicating that this cell subset contributes to intrahepatic inflammation via its proinflammatory cytokine profile (38). As the spectrum of liver diseases in our study cohort was heterogeneous, ranging from alcoholic liver disease to HCV infection, and the size of the study cohort was small, it was not possible to determine differences between liverand peripheral blood-derived monocytes and $\mathrm{M} \varphi$ subsets in the context of the underlying liver diseases. Taken together, our data suggest that livers contained a higher proportion of developing transitional $\mathrm{M} \varphi$, which might be due to a high level of inflammation in the liver samples included in this study.
Contrary to mouse liver-derived $\mathrm{M} \varphi$ (mouse KCs) that can be distinguished from circulating monocytes by expression of F4/80 glycoprotein, a member of the EGF-TM7 receptor family $(39,40)$, markers clearly distinguishing human liverderived macrophages from monocytes are lacking. CD68 has been suggested as a possible marker for human KCs, although it is not-exclusive (41). Recently, the V-set and Ig domaincontaining 4 (VSIG4), also known as CRIg, has been suggested to identify mice and human macrophages in tissues, as it is largely absent on circulating monocytes (17, 18, 22-24, 42). VSIG4 has several roles in immune regulation serving as an immunosuppressive and anti-inflammatory molecule, and was also described to efficiently phagocytose bacteria and 

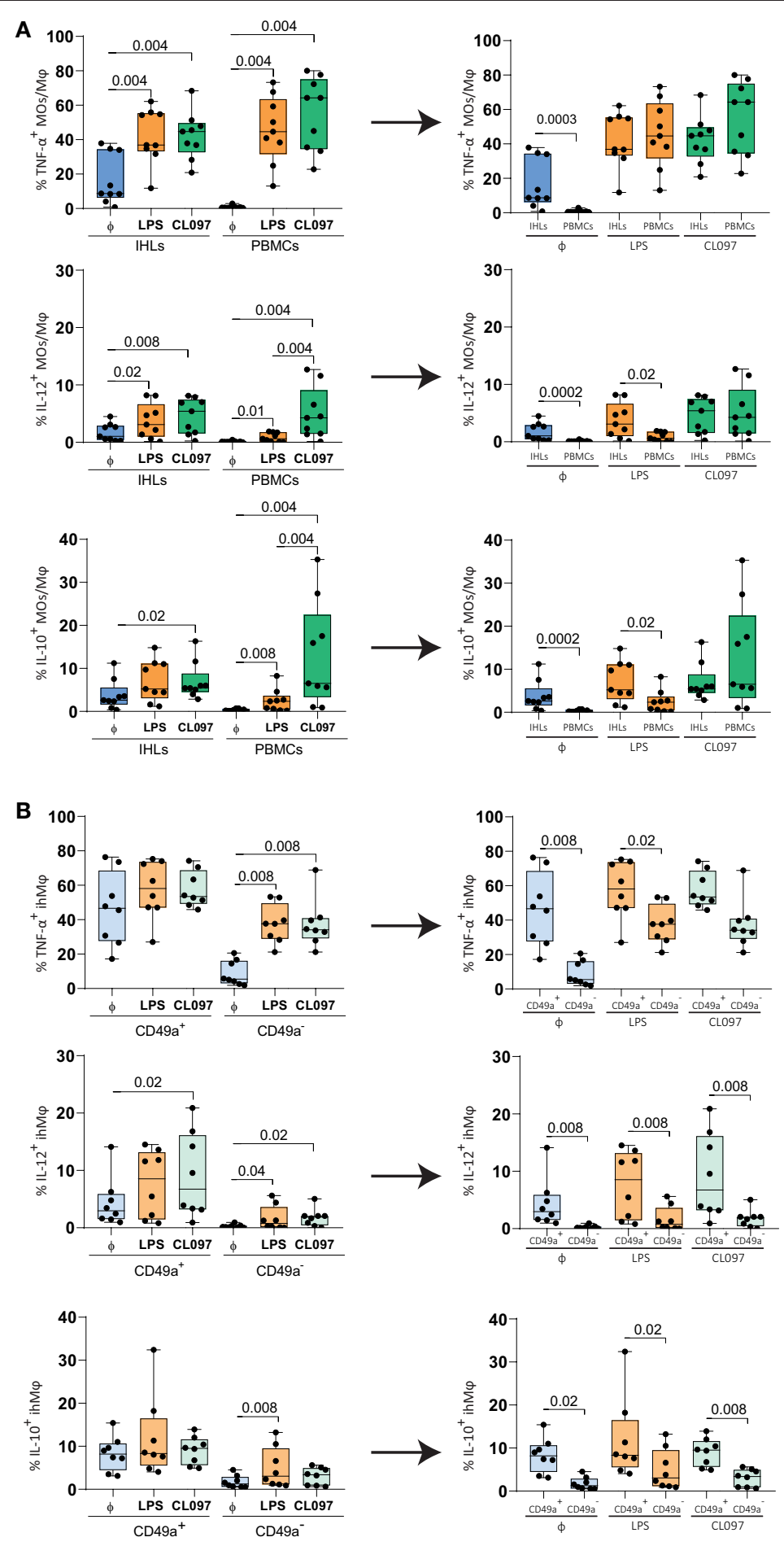

FIGURE 4 | Functional responses of paired ihM $\varphi$ and pbMOs to CL097 and LPS stimulations compared to unstimulated cells. (A) Scatter plots showing the comparison of the frequencies of TFN- $\alpha^{+}$cells (top), IL- $12^{+}$cells (middle) and IL-10 $+0^{+}$cells (bottom) between pbMOs and ihM $\phi$ stimulated with LPS (orange) or CL097 (green), to unstimulated cells (blue) $(n=9)$. (B) Comparison of the frequency of TFN- $\alpha^{+}$ihM $\varphi$ (top) IL-12 ${ }^{+}$ihM $\varphi$ (middle) and IL-10+ (bottom) cells between $\mathrm{CD}_{49}{ }^{+}$and CD49a${ }^{-}$ihM $\varphi$ once stimulated with LPS (light orange) or CL097 (light green), to unstimulated cells (light blue) $(n=8)$. Medians and min-max range are showed. Liver and PBMCs comparisons were analyzed with a Mann-Whitney test and corrected for test-multiplicity using the original FDR method of Benjamini and Hochberg. Data in (B) was analyzed using a Wilcoxon matched-pairs signed rank test when comparing IHL populations. The arrows represent the reorganization of the same data. One sample was excluded from B due to the low amount of cells within the CD49a ${ }^{+}$ihM $\varphi$ gating. $\Phi$ : unstimulated. Only statistically significant p-values are shown. 
A

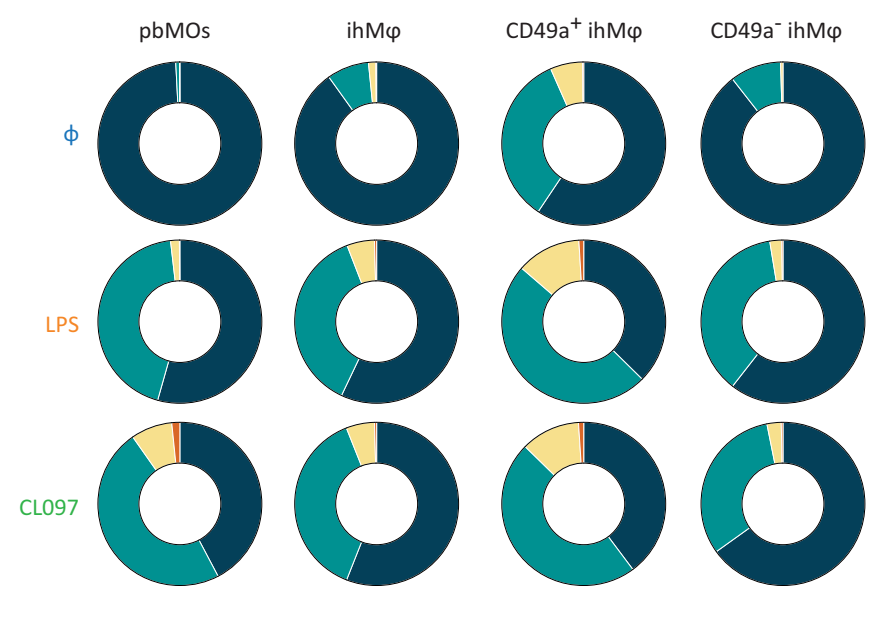

B

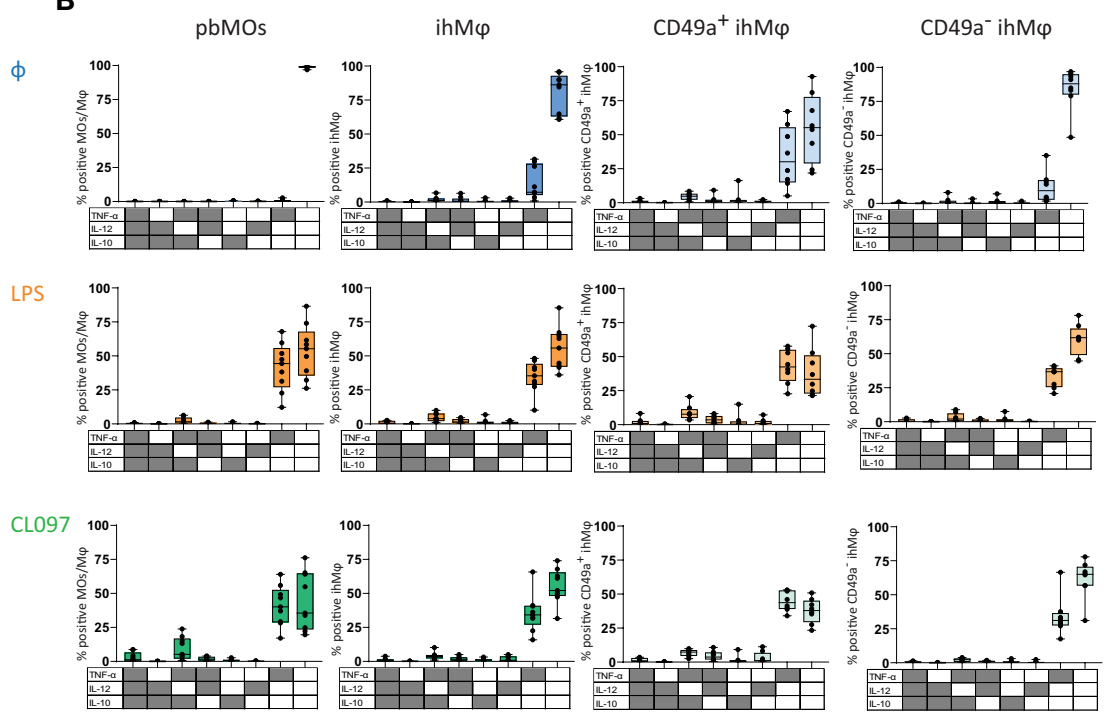

FIGURE 5 | Polyfunction on cytokine responses of paired ihM $\varphi$ and pbMOs. (A) Pie chart summarizing the percentage of MOs/M $\mathrm{M}$ expressing $0,1,2$, or 3 cytokines, without stimulation or following LPS- or CL097-stimulation (blue: 0; green 1; yellow: 2; orange: 3 ) ( $n=9$ for pbMOs and ihM $\varphi, n=8$ for $\mathrm{CD} 49 \mathrm{a}^{+}$inM $\varphi$ and $\mathrm{CD} 49 \mathrm{a}^{-}$ ihM $\varphi$ ). (B) Boolean gating of cells expressing TNF- $\alpha$, IL-12, and/or IL-10 on LPS-(orange), CL097-(green)stimulated pbMOs, ihM $\varphi, C^{2} 49 a^{+}$ihM $\varphi$, and CD49a ${ }^{-}$ihM $\varphi$. Unstimulated (blue) condition was used to calculate the baseline production of cytokines. One sample was excluded from the ihM $\varphi$ analysis due to the low amount of cells within the $\mathrm{CD} 49 \mathrm{a}^{+} \mathrm{ihM} \varphi$ gating Medians and min-max range are showed.

boost elimination of intracellular microorganisms (22, 43). A recent publication furthermore suggested the presence of two differentiated monocyte $/ \mathrm{M} \varphi$ subsets in human liver samples, dependent on the expression of the PRR MARCO on the cell surface (23). Previous studies have also shown that the expression of CD49a identifies a population of tissue-resident $\mathrm{NK}$ and $\mathrm{T}$ cells in mice and humans (11-14, 27, 44-46). CD49a is the $\alpha 1$ subunit of $\alpha 1 \beta 1$ integrin, a receptor associated with adhesion of lymphocytes to collagen IV. In line with these observations for $\mathrm{NK}$ and $\mathrm{T}$ cells, we detected CD49aexpression exclusively on liver-derived $\mathrm{M} \varphi$, while $\mathrm{CD} 49 \mathrm{a}^{+} \mathrm{MOs}$ were largely absent in peripheral blood. Within $\operatorname{ihM} \varphi$, the expression of CD69, CD80, CD83, and CD86 was higher on $\mathrm{CD} 49 \mathrm{a}^{+} \mathrm{M} \varphi$ compared to $\mathrm{CD} 49 \mathrm{a}^{-} \mathrm{M} \varphi$. Our data using both flow cytometry and immunofluorescence staining of liver tissue samples furthermore showed that $\mathrm{ihM} \varphi$ consisted of a variety of subpopulations expressing different combinations of CD49a, VSIG4 and MARCO.

The liver has been traditionally described as a tolerogenic organ, with Kupffer cells (KCs) and dendritic cells representing the main cell subsets mediating tolerance. KCs suppress $\mathrm{CD} 8^{+}$ $\mathrm{T}$ cell activity by several mechanisms, including overexpression 
of Fas-Ligand, which induces $\mathrm{CD}^{+} \mathrm{T}$ cell destruction (47); overexpression of PD-L1, which leads to cell exhaustion through PD-1 receptor on $\mathrm{T}$ cells (48); or secretion of IL-10, an immunosuppressive cytokine (49, 50). Although intrahepatic KCs have been shown in mice and rats to express TLRs $(51,52)$, those cells are hypo-responsive to endogenous LPS and also other TLR ligands (53). Nonetheless, novel antigens arising from microbial infections, such as influenza in humans, strongly activate liver macrophages (54). Predisposition for endotoxin-tolerance might be primarily due to an adjustment to PAMPs arising from intestinal microbiota, which are not posing an immunological threat. This effect might be particularly relevant during inflammation, when higher gut translocation of bacterial and viral PAMPs is observed (6). Human macrophages are classified in M1 or M2 according to their functional properties: M1 macrophages are pro-inflammatory, by secreting TNF- $\alpha$ and IL-12, and induce a Th1 and Th17 response, while M2 macrophages, secreting IL-10, have been shown to be anti-inflammatory and recruit a Th2 response (55). Our results are in line with endotoxin-tolerance, as $\mathrm{CD}_{49} \mathrm{a}^{+} \mathrm{ihM} \varphi$ contained a higher proportion of cells expressing activation markers and higher cytokine levels at baseline, but did not strongly react to further TLR4 or TLR7/8 stimuli. Moreover, the majority of cytokine-producing cells within the $\mathrm{CD} 49 \mathrm{a}^{+} \mathrm{ihM} \varphi$ population exhibited an M1 phenotype, as they produced TNF- $\alpha$ and/or IL-12 at baseline. Since the production of IL-12 by monocytes/macrophages upon LPS-exposure was shown to be dependent on previous IFN- $\gamma$-mediated priming (56), our data indicate that IFN- $\gamma$-producing cells, such as intrahepatic NK or $\mathrm{T}$ cells, might be able to prime $\mathrm{CD} 49 \mathrm{a}^{+} \mathrm{ihM} \varphi$.

In conclusion, we showed in this study that human intrahepatic macrophages can co-express CD49a, VSIG4 and/or MARCO. CD $49 \mathrm{a}^{+} \mathrm{ihM} \varphi$ had distinct phenotypical patterns as well as functional properties, when compared to $\mathrm{CD}_{4} 9 \mathrm{a}^{-} \mathrm{ihM} \varphi$ and peripheral blood-derived monocytes.

\section{ETHICS STATEMENT}

This study was carried out in accordance with the recommendations of the Institutional Review Board of the medical faculty at the University of Hamburg (PV4898, PV4081,

\section{REFERENCES}

1. Manzella A, Ohtomo K, Monzawa S, Lim JH. Schistosomiasis of the liver. Abdom Imaging. (2008) 33:144-50. doi: 10.1007/s00261-007-9329-7

2. Crispe IN. Immune tolerance in liver disease. Hepatology. (2014) 60:210917. doi: 10.1002/hep. 27254

3. Huang $\mathrm{H}, \mathrm{Lu} \mathrm{Y}$, Zhou $\mathrm{T}, \mathrm{Gu} \mathrm{G}$, Xia Q. Innate immune cells in immune tolerance after liver transplantation. Front Immunol. (2018) 9:2401. doi: 10.3389/fimmu.2018.02401

4. Crispe IN. The liver as a lymphoid organ. Annu Rev Immunol. (2009) 27:14763. doi: 10.1146/annurev.immunol.021908.132629

5. Gao B, Jeong WI, Tian Z. Liver: an organ with predominant innate immunity. Hepatology. (2008) 47:729-36. doi: 10.1002/hep.22034
PV4780, and WF-021/11) with written informed consent from all subjects. All subjects gave written informed consent in accordance with the Declaration of Helsinki. The protocol was approved by the Institutional Review Board of the medical faculty at the University of Hamburg.

\section{AUTHOR CONTRIBUTIONS}

GM, HG, SL, and MA: conceived and designed the experiments. GM, HG, AEL, JK, FF, AN, and SL: performed the experiments. GM, HG, AEL, WS, LUH, AEZ, SML, KR, and TP: processed the liver samples. GM, HG, FF, JK, and SL: analyzed the data. GM and SL: performed the statistical analysis. $\mathrm{MK}, \mathrm{BN}$, and KJO: provided the clinical samples. CS, MD, and MA: provided resources. GM, SL, and MA: drafted the paper. All authors critically reviewed and approved the final version of the paper.

\section{FUNDING}

This work was founded by the Deutsche Forschungsgemeinschaft (SFB 841), the Helmut and Hannelore Greve Foundation and the YAEL Foundation. HG, LUH, and AEZ were financially supported by the Graduiertenkolleg (GRK SFB841) from the University Medical Center Hamburg-Eppendorf (UKE). AEL and TP were financially supported by the KFO306.

\section{ACKNOWLEDGMENTS}

The authors would like to thank all donors, cohort organizers, nurses, and doctors at the Department of Hepatobiliary and Transplant Surgery at UKE (University Medical Center Hamburg-Eppendorf, Hamburg, Germany) and at the Department of General and Abdominal Surgery (Asklepios Hospital Barmbek, Hamburg, Germany). The publication of this article was funded by the Open Access Fund of the Leibniz Association.

\section{SUPPLEMENTARY MATERIAL}

The Supplementary Material for this article can be found online at: https://www.frontiersin.org/articles/10.3389/fimmu. 2019.01247/full\#supplementary-material

6. Talwani R, Gilliam BL, Howell C. Infectious diseases and the liver. Clin Liver Dis. (2011) 15:111-30. doi: 10.1016/j.cld.2010.09.002

7. Heymann F, Tacke F. Immunology in the liver-from homeostasis to disease. Nat Rev Gastroenterol Hepatol. (2016) 13:88110. doi: $10.1038 /$ nrgastro.2015.200

8. Werner M, Driftmann S, Kleinehr K, Kaiser GM, Mathe Z, Treckmann JW, et al. All-in-one: advanced preparation of human parenchymal and non-parenchymal liver cells. PLoS ONE. (2015) 10:e0138655. doi: 10.1371/journal.pone.01 38655

9. Ziegler-Heitbrock L, Ancuta P, Crowe S, Dalod M, Grau V, Hart DN, et al. Nomenclature of monocytes and dendritic cells in blood. Blood. (2010) 116:e74-80. doi: 10.1182/blood-2010-02-258558 
10. Liaskou E, Zimmermann HW, Li KK, Oo YH, Suresh S, Stamataki $Z$, et al. Monocyte subsets in human liver disease show distinct phenotypic and functional characteristics. Hepatology. (2013) 57:38598. doi: 10.1002/hep.26016

11. Marquardt N, Beziat V, Nystrom S, Hengst J, Ivarsson MA, Kekalainen E, et al. Cutting edge: identification and characterization of human intrahepatic CD49a+ NK cells. J Immunol. (2015) 194:2467-71. doi: 10.4049/jimmunol.1402756

12. Peng H, Jiang X, Chen Y, Sojka DK, Wei H, Gao X, Sun R, Yokoyama WM, Tian Z, Liver-resident NK cells confer adaptive immunity in skin-contact inflammation. J Clin Invest. (2013) 123:1444-56. doi: 10.1172/JCI66381

13. Cheuk S, Schlums H, Gallais Serezal I, Martini E, Chiang SC, Marquardt N, et al. CD49a expression defines tissue-resident CD8+ T cells poised for cytotoxic function in human skin. Immunity. (2017) 46:287-300. doi: 10.1016/j.immuni.2017.01.009

14. Martrus G, Kautz T, Lunemann S, Richert L, Glau L, Salzberger W, et al. Proliferative capacity exhibited by human liver-resident CD49a+CD25+ NK cells. PLoS ONE. (2017) 12:e0182532. doi: 10.1371/journal.pone.01825320

15. Langeneckert AE, Lunemann S, Martrus G, Salzberger W, Hess LU, Ziegler $\mathrm{AE}$, et al. CCL21-expression and accumulation of CCR7 $(+) \mathrm{NK}$ cells in livers of patients with primary sclerosing cholangitis. Eur J Immunol. (2019) 49:758-69. doi: 10.1002/EJI.201847965/v2/response1

16. Vogt L, Schmitz N, Kurrer MO, Bauer M, Hinton HI, Behnke S, et al. VSIG4, a B7 family-related protein, is a negative regulator of $\mathrm{T}$ cell activation. J Clin Invest. (2006) 116:2817-26. doi: 10.1172/JCI25673

17. He JQ, Wiesmann C, van Lookeren Campagne M. A role of macrophage complement receptor CRIg in immune clearance and inflammation. Mol Immunol. (2008) 45:4041-7. doi: 10.1016/j.molimm.2008.07.011

18. Liao Y, Guo S, Chen Y, Cao D, Xu H, Yang C, et al. VSIG4 expression on macrophages facilitates lung cancer development. Lab Invest. (2014) 94:70615. doi: 10.1038/labinvest.2014.73

19. Guo S, Yang C, Mei F, Wu S, Luo N, Fei L, et al. Down-regulation of Z39Ig on macrophages by IFN-gamma in patients with chronic HBV infection. Clin Immunol. (2010) 136:282-91. doi: 10.1016/j.clim.2010.03.007

20. Li J, Diao B, Guo S, Huang X, Yang C, Feng Z, et al. VSIG4 inhibits proinflammatory macrophage activation by reprogramming mitochondrial pyruvate metabolism. Nat Commun.

(2017) 8:1322. doi: 10.1038/s41467-017-01327-4

21. Krenkel O, Tacke F. Liver macrophages in tissue homeostasis and disease. Nat Rev Immunol. (2017) 17:306-21. doi: 10.1038/nri.2017.11

22. Irvine $\mathrm{KM}$, Banh $\mathrm{X}$, Gadd VL, Wojcik KK, Ariffin JK, Jose S, et al. CRIg-expressing peritoneal macrophages are associated with disease severity in patients with cirrhosis and ascites. JCI Insight. (2016) 1:e86914. doi: 10.1172/jci.insight.86914

23. MacParland SA, Liu JCX,Ma Z, Innes BT, Bartczak AM, Gage BK, et al. Single cell RNA sequencing of human liver reveals distinct intrahepatic macrophage populations. Nat Commun. (2018) 9:4383. doi: 10.1038/s41467-018-06318-7

24. Jung K, Kang M, Park C, Hyun Choi Y, Jeon Y, Park SH, et al. Protective role of $\mathrm{V}$-set and immunoglobulin domain-containing 4 expressed on kupffer cells during immune-mediated liver injury by inducing tolerance of liver T- and natural killer T-cells. Hepatology. (2012) 56:1838-48. doi: 10.1002/hep.25906

25. Salzberger W, Martrus G, Bachmann K, Goebels H, Hess L, Koch $\mathrm{M}$, et al. Tissue-resident NK cells differ in their expression profile of the nutrient transporters Glut1, CD98 and CD71. PLoS ONE. (2018) 13:e0201170. doi: 10.1371/journal.pone.0201170

26. Lunemann S, Schobel A, Kah J, Fittje P, Holzemer A, Langeneckert AE, et al. Interactions between KIR3DS1 and HLA-F activate natural killer cells to control HCV replication in cell culture. Gastroenterology. (2018) 155:136671.e3. doi: 10.1053/j.gastro.2018.07.019

27. Lunemann S, Martrus G, Goebels H, Kautz T, Langeneckert A, Salzberger W, et al. Hobit expression by a subset of human liver-resident CD56bright natural killer cells. Sci Rep. (2017) 7:6676. doi: 10.1038/s41598-01706011-7

28. Taghizadeh RR, Cetrulo KJ, Cetrulo CL. Collagenase impacts the quantity and quality of native mesenchymal stem/stromal cells derived during processing of umbilical cord tissue. Cell Transplant. (2018) 27:18193. doi: $10.1177 / 0963689717744787$
29. Scully EP, Lockhart A, Garcia-Beltran W, Palmer CD, Musante C, Rosenberg $\mathrm{E}$, et al. Innate immune reconstitution with suppression of HIV-1. JCI Insight. (2016) 1:e85433. doi: 10.1172/jci.insight.85433

30. Testi R, Cifone MG, Santoni A. Role of CD69 in NO production by human monocytes. Res Immunol. (1995) 146:6823. doi: 10.1016/0923-2494(96)84917-0

31. Cao W, Lee SH, Lu J. CD83 is preformed inside monocytes, macrophages and dendritic cells, but it is only stably expressed on activated dendritic cells. Biochem J. (2005) 385:85-93. doi: 10.1042/BJ20040741

32. Fleischer J, Soeth E, Reiling N, Grage-Griebenow E, Flad HD, Ernst M. Differential expression and function of CD80 (B7-1) and CD86 (B72) on human peripheral blood monocytes. Immunology. (1996) 89:5928. doi: 10.1046/j.1365-2567.1996.d01-785.x

33. Gordon S, Pluddemann A, Martinez Estrada F. Macrophage heterogeneity in tissues: phenotypic diversity and functions. Immunol Rev. (2014) 262:3655. doi: 10.1111/imr.12223

34. Mencin A, Kluwe J, Schwabe RF. Toll-like receptors as targets in chronic liver diseases. Gut. (2009) 58:704-20. doi: 10.1136/gut.2008.156307

35. Horst AK, Neumann K, Diehl L, Tiegs G. Modulation of liver tolerance by conventional and nonconventional antigen-presenting cells and regulatory immune cells. Cell Mol Immunol. (2016) 13:277-92. doi: 10.1038/cmi.2015.112

36. Mukherjee R, Kanti Barman P, Kumar Thatoi P, Tripathy R, Kumar Das B, Ravindran B. Non-classical monocytes display inflammatory features: validation in sepsis and systemic lupus erythematous. Sci Rep. (2015) 5:13886. doi: $10.1038 /$ srep 13886

37. Ziegler-Heitbrock L. The CD14+ CD16+ blood monocytes: their role in infection and inflammation. J Leukoc Biol. (2007) 81:584-92. doi: 10.1189/jlb.0806510

38. Zimmermann HW, Seidler S, Nattermann J, Gassler N, Hellerbrand C, Zernecke A, et al. Functional contribution of elevated circulating and hepatic non-classical CD14CD16 monocytes to inflammation and human liver fibrosis. PLoS ONE. (2010) 5:e11049. doi: 10.1371/journal.pone.00 11049

39. Mass E, Ballesteros I, Farlik M, Halbritter F, Gunther P, Crozet L, et al. Specification of tissue-resident macrophages during organogenesis. Science. (2016) 353:aaf4238. doi: 10.1126/science.aaf4238

40. Scott CL, Zheng F, De Baetselier P, Martens L, Saeys Y, De Prijck S, et al. Bone marrow-derived monocytes give rise to self-renewing and fully differentiated Kupffer cells. Nat Commun. (2016) 7:10321. doi: 10.1038/ncomms10321

41. Antoniades CG, Quaglia A, Taams LS, Mitry RR, Hussain M, Abeles R, et al. Source and characterization of hepatic macrophages in acetaminopheninduced acute liver failure in humans. Hepatology. (2012) 56:73546. doi: 10.1002/hep. 25657

42. Helmy KY, Katschke KJ, Jr., Gorgani NN, Kljavin NM, Elliott JM, et al. CRIg: a macrophage complement receptor required for phagocytosis of circulating pathogens. Cell. (2006) 124:915-27. doi: 10.1016/j.cell.2005.12.039

43. Kim KH, Choi BK, Song KM, Cha KW, Kim YH, Lee H, et al. CRIg signals induce anti-intracellular bacterial phagosome activity in a chloride intracellular channel 3-dependent manner. Eur J Immunol. (2013) 43:66778. doi: 10.1002/eji.201242997

44. Zhang LH, Shin JH, Haggadone MD, Sunwoo JB. The aryl hydrocarbon receptor is required for the maintenance of liver-resident natural killer cells. $J$ Exp Med. (2016) 213:2249. doi: 10.1084/jem.20151998

45. Nizard M, Roussel H, Diniz MO, Karaki S, Tran T, Voron T, et al. Induction of resident memory T cells enhances the efficacy of cancer vaccine. Nat Commun. (2017) 8:15221. doi: 10.1038/ncomms15221

46. Mackay LK, Rahimpour A, Ma JZ, Collins N, Stock AT, Hafon ML, et al. The developmental pathway for CD103(+)CD8+ tissue-resident memory T cells of skin. Nat Immunol. (2013) 14:1294-301. doi: 10.1038/ni.2744

47. Sun Z, Wada T, Maemura K, Uchikura K, Hoshino S, Diehl AM, et al. Hepatic allograft-derived Kupffer cells regulate $\mathrm{T}$ cell response in rats. Liver Transpl. (2003) 9:489-97. doi: 10.1053/jlts.2003.50091

48. Wu K, Kryczek I, Chen L, Zou W, Welling TH. Kupffer cell suppression of CD8+ $\mathrm{T}$ cells in human hepatocellular carcinoma is mediated by B7-H1/programmed death-1 interactions. Cancer Res. (2009) 69:806775. doi: 10.1158/0008-5472.CAN-09-0901 
49. Yuan F, Zhang W, Mu D, Gong J. Kupffer cells in immune activation and tolerance toward HBV/HCV infection. Adv Clin Exp Med. (2017) 26:73945. doi: $10.17219 /$ acem/62759

50. Erhardt A, Biburger M, Papadopoulos T, Tiegs G. IL-10, regulatory T cells, and Kupffer cells mediate tolerance in concanavalin A-induced liver injury in mice. Hepatology. (2007) 45:475-85. doi: 10.1002/hep. 21498

51. Kawai T, Akira S. Toll-like receptors and their crosstalk with other innate receptors in infection and immunity. Immunity. (2011) 34:63750. doi: 10.1016/j.immuni.2011.05.006

52. Nakamoto N, Kanai $\mathrm{T}$. Role of toll-like receptors in immune activation and tolerance in the liver. Front Immunol. (2014) 5:221. doi: 10.3389/fimmu.2014.00221

53. Thomson AW, Knolle PA. Antigen-presenting cell function in the tolerogenic liver environment. Nat Rev Immunol. (2010) 10:753-66. doi: 10.1038/ nri2858

54. Polakos NK, Cornejo JC, Murray DA, Wright KO, Treanor JJ, Crispe IN, et al. Kupffer cell-dependent hepatitis occurs during influenza infection. Am J Pathol. (2006) 168:1169-78; quiz 1404-5. doi: 10.2353/ajpath.2006. 050875
55. Italiani P, Boraschi D. From Monocytes to M1/M2 Macrophages: phenotypical vs. functional differentiation. Front Immunol. (2014) 5:514. doi: 10.3389/fimmu.2014.00514

56. Dobashi K, Aihara M, Araki T, Shimizu Y, Utsugi M, Iizuka K, et al. Regulation of LPS induced IL-12 production by IFN-gamma and IL-4 through intracellular glutathione status in human alveolar macrophages. Clin Exp Immunol. (2001) 124:290-6. doi: 10.1046/j.1365-2249.2001.01535.x

Conflict of Interest Statement: The authors declare that the research was conducted in the absence of any commercial or financial relationships that could be construed as a potential conflict of interest.

Copyright (c) 2019 Martrus, Goebels, Langeneckert, Kah, Flomm, Ziegler, Niehrs, Löbl, Russu, Hess, Salzberger, Poch, Nashan, Schramm, Oldhafer, Dandri, Koch, Lunemann and Altfeld. This is an open-access article distributed under the terms of the Creative Commons Attribution License (CC BY). The use, distribution or reproduction in other forums is permitted, provided the original author(s) and the copyright owner(s) are credited and that the original publication in this journal is cited, in accordance with accepted academic practice. No use, distribution or reproduction is permitted which does not comply with these terms. 